\title{
BURNOUT AND ITS CORRELATES - AN EMPIRICAL STUDY CONDUCTED AMONG EDUCATION, HIGHER EDUCATION AND HEALTH CARE PROFESSIONALS
}

\section{Urszula Załuska}

Wrocław University of Economics, Wrocław, Poland e-mail: urszula.zaluska@ue.wroc.pl

\section{Magdalena Ślazyk-Sobol}

University of Wrocław, Wrocław, Poland

e-mail: magdalena.slazyk-sobol@uwr.edu.pl

\section{Dorota Kwiatkowska-Ciotucha}

Wrocław University of Economics, Wrocław, Poland e-mail: dorota.kwiatkowska@ue.wroc.pl

(C) 2018 Urszula Załuska, Magdalena Ślazyk-Sobol, Dorota Kwiatkowska-Ciotucha

This is an open access article distributed under the Creative Commons Attribution-NonCommercial-NoDerivs license (http://creativecommons.org/licenses/by-nc-nd/3.0/)

DOI: 10.15611/eada.2018.1.02

\begin{abstract}
Burnout has serious consequences both for individuals and the organizations they work in. The issue generates interest among psychologist and management professionals and - according to the subject literature - there is a growing demand for helping those professional groups who face the risk of experiencing the negative effects of an exhausting working life. The aim of this paper is to characterize the phenomenon of burnout in Poland in the selected professional groups. The primary research was conducted on June and July 2017 on the group of 153 people working in the following areas: healthcare, education, higher education. Two types of questionnaire were used for the purpose of this research. The first was an LBQ Burnout Questionnaire, which is an adaptation of an Italian Link Burnout Questionnaire. The other questionnaire was originally devised by the authors to assess the perception of the phenomenon among Polish employees. The article presents the results concerning all the methods used during research and compared the results of the LBQ and the original questionnaire.
\end{abstract}

Keywords: burnout, statistical analysis, areas of healthcare, education and higher education.

\section{Introduction}

The aim of this paper is to analyze how the phenomenon of burnout is perceived by the education, higher education and health care professionals in Poland. It covers the results of an empirical study concerning burnout and its correlates among such professional groups as: teachers, academics, health care workers and the carers of 
persons with disabilities. The conclusions that are to be presented are a part of a greater international research project that relates the prevention of burnout. The current interest in burnout is associated with the increasing need for supporting professional groups that are especially vulnerable to the negative effects of an exhausting work environment, i.e. health care and education workers [Maslach, Leiter 2008; 2010; 2011]. Furthermore, in the authors' view, it is crucial to examine the possible symptoms of burnout among higher education professionals. This is due to the fact that there are no empirical studies investigating the issue of burnout among academics who are expected to reconcile research work with teaching and administrative duties.

To meet the objective of the research following questions had to be asked:

1. What is the nature of the phenomenon of burnout according to the professionals from the previously mentioned professional groups?

2. Is there an association between the level of burnout (and its components) and demographic factors such as work aversion or pursuing one's hobbies? If so, how could it be characterized?

For more than forty years the phenomenon of burnout has been generating a great interest among psychologists and management professionals. The literature concerning this subject includes many studies and a lot of research concerning the diagnosis of burnout and its predictors, especially among the professionals who are engaged in helping relationships with their patients, clients or pupils. In the pioneering empirical studies, firstly carried out by H.J. Freudenberg and then by Ch. Maslach, this psychological syndrome was described as a particular state that affects an individual who has been bearing high long-term emotional and psychophysical costs and was defined as apsychological syndromeof emotional exhaustion, depersonalization, and lowered self-efficacy, that is likely to occur among professionals having interpersonal relationships [Maslach, Jakcson 1981; 2011].

The subject literature defines burnout as a "troubled relationship" between a worker and a particular work environment [Maslach, Leiter 2008; Santinello 2014]. The reason behind emotional exhaustion, growing cynicism and distance in interpersonal relationships, lowered level of effectiveness and career disappointment is the mismatch between an individual and his/her post and professional environment. Psychologists characterize this type of environment in terms of stressors: work overload (the complexity and the number of tasks), lack of sense of control and influence, no rewards, no sense of fellowship in interpersonal relationships, an organizational system deprived of values and fairness. The available literature points to the many negative consequences of burnout that could affect individuals (psychological costs) as well as organizations (absenteeism, lower effectiveness at work, group conflicts, diseases and long-term health problems of employees).

The observations on the current job market in Poland indicate that the burnout problem is escalating every year. However, the scale of the phenomenon is hard to determine, because there is no Polish nationwide study concerning this matter. The 
research that can be used as a starting point was carried out by Prof. A. Bassam in collaboration with the Marshall Office and the Regional Centre for Occupational Medicine in the Kujawsko-Pomorskie voivodship [Molenda, Hąbek 2015]. The study was carried out among four thousand employees working in different companies. The results were surprising: the "burnt-out" or "just-before-burnout" employees amounted to $48 \%$ which suggest how serious the scale of the phenomenon could be globally and how important it is to take preventive action in this respect.

\section{The research material and analytical tools used during the research}

The research was conducted on June and July 2017 on a group of 153 people working in the following areas: healthcare (nurses, carers of persons with disabilities), education (teachers), higher education (academic teachers). Table 1 groups the respondents on the basis of the survey demographic questions.

There was a significant prevalence of women over men in the sample (128 versus 25 ), which clearly reflects the extent to which the teaching and nursing profession are female-dominated. The sample is divided by age as follows: the respondents aged 46-55 (67 people) and those aged 36-45 (46 people) form the most numerous

Table 1. The division of the sample by the characteristics included in the demographic questions

\begin{tabular}{|c|c|c|c|}
\hline \multicolumn{4}{|c|}{ Workplace } \\
\hline Healthcare (MC) & \multicolumn{2}{|c|}{ Education (ED) } & Higher education (HE) \\
\hline 64 & \multicolumn{2}{|c|}{46} & 43 \\
\hline \multicolumn{4}{|c|}{ Place of residence } \\
\hline Countryside & $\begin{array}{c}\text { City of less than } 50000 \\
\text { inhabitants }\end{array}$ & $\begin{array}{c}\text { City of } 50000- \\
200000 \text { inhabitants }\end{array}$ & $\begin{array}{c}\text { City of over } 200000 \\
\text { inhabitants }\end{array}$ \\
\hline 13 & 28 & 30 & 82 \\
\hline \multicolumn{4}{|c|}{ Type of institution } \\
\hline Private sector & \multicolumn{2}{|c|}{ Public sector } & Mixed capital \\
\hline 36 & \multicolumn{2}{|c|}{112} & 5 \\
\hline \multicolumn{4}{|c|}{ Sex } \\
\hline \multicolumn{2}{|c|}{ Male } & \multicolumn{2}{|c|}{ Female } \\
\hline \multicolumn{2}{|c|}{25} & \multicolumn{2}{|c|}{128} \\
\hline \multicolumn{4}{|c|}{ Age } \\
\hline 35 years or less & $36-45$ years & $46-55$ years & 56 years and more \\
\hline 20 & 46 & 67 & 20 \\
\hline \multicolumn{4}{|c|}{ Seniority } \\
\hline Under 5 years & 6-15 years & $16-25$ years & Over 25 years \\
\hline 8 & 42 & 51 & 52 \\
\hline
\end{tabular}

Source: own calculations. 
groups; the other two groups, i.e. " 35 years and less" and " 55 and more" involved 20 participants. 52 respondents have been working in their profession for over 25 years, 51 people have gained the seniority of 16 to 25 years, 42 respondents declared 5 to 15 years of professional experience and 8 people have been working in their profession less than 5 years. Most of the respondents - due to the formal requirements in the analyzed professions - had higher education (115 people); others had secondary education (that includes 14 people who graduated from Further Education College).

Two types of questionnaire were used for the purpose of this research. The first was an LBQ Burnout Questionnaire, which is an adaptation of the Italian Link Burnout Questionnaire ${ }^{1}$ [Santinello 2008; 2014]. The other questionnaire was originally devised by the authors to assess the perception of the phenomenon among Polish employees.

The LBQ questionnaire allows to diagnose four key aspects of burnout, i.e. psycho-physical exhaustion, lack of involvement in relationships with clients (patients, pupils, etc.), lack of sense of professional self-efficacy (effectiveness) and career disappointment. The psycho-physical aspect includes the self-assessment of one's own psycho-physical resources like stress level, mental pressure and fatigue. The aspect concerning relationships with recipients raises the issue of the quality of the relationships (with patients, pupils, clients, etc.) and helps to study an individual and subjective attitude towards social environment at work. The aspect of professional effectiveness refers to how an individual assesses his/her professional competence, while the aspect regarding career disappointment concerns the existential expectations that an individual holds for their work, job satisfaction, enthusiasm for work and the sense of professional fulfillment. The tool possesses satisfactory psychometric characteristics. It consists of 24 positions - statements that describe the feelings of a subject towards his/her work. Respondents answer the questions using the six-level frequency scale (the range of which is: "never", "seldom", "onceor a few times per week", "roughly once per week", "a few times per week", "everyday"). The results of the LBQ survey are presented as sten scores. ${ }^{2}$ The LBQ tool diagnoses the level of burnout in reference to three states experienced by subjects: low $(1-3$ scores $)$, average ( $4-7$ scores) and high ( $8-10$ scores). It enables to analyze four aspects (dimensions) of burnout. If any of the dimensions of the questionnaire receives high scores it means - according to the subject matter - that there is a potential threat of burnout in this particular area.

The original questionnaire was to assess the extent to which the phenomenon is recognized among the Polish employees. It comprised 26 questions, 22 of which were closed, 4 questions were open and 6 questions were demographic ones. The

${ }^{1}$ In 2013 a team from the Psychological Test Laboratory of the Polish Psychological Association conducted standardization and validation studies among five professional groups who are engaged in helping other people (teachers, nurses, medical professionals, uniformed services, in total $\mathrm{N}=995$ people with at least one year of seniority, aged 19-65, from all around Poland).

2 Sten scores are often used in psychological tests. It consists of 10 levels and its structure guarantees that the median equals 5.5 and the standard deviation equals 2 . 
closed questions were twofold: they either determined the occurrence of a given factor (when a respondent answered one or more questions from the cafeteria) or assessed the level of occurrence of a given factor (on a 11-level scale, from 0 to 10).

\section{The results of the analysis of the data gathered by applying the original questionnaire and the LBQ}

The scope of the analysis covered the responses given in answer to the questions in the original questionnaire, which are related to the occurrence of the symptoms of burnout. The authors of the article were particularly interested to find answers for the questions regarding:

- type of work (question no. 3),

- the respondents' understanding of burnout and its symptoms (question no. 7),

- the importance of the topic of burnout in a given professional group (question no. 12),

- the difficulty in admitting to be burned-out by using formal means (question no. 14).

The questions measured the intensity level of a particular factor on a 11-level scale (from 0 to 10). Table 2 displays the mean values received for each question, respectively for the research sample and for the professional groups.

In the analysis an attempt was made to assess to what extent the factors contributing to the occurrence of the symptoms of burnout are heterogeneous. In order to validate the significance of the differences between the importance of the analyzed factors (that had been observed among the subgroups of the respondents) a one-factor analysis of variance was used ${ }^{3}$. With the goal of choosing the best way to calculate the empirical statistics in mind, the analysis was preceded by assessing the equality of variances in the analyzed subgroups ${ }^{4}$ (SPSS, v. 24.0, Levene's test). The equality of variances was observed in questions $3 c, 3 i$ and $3 p(\alpha \leq 0,05)$. To identify the differences between the professional groups that would be statistically significant, multiple comparison follow-up tests were used ${ }^{5}$ (SPSS, ver. 24.0, Sheffe's test, Tukey's test, Tamhane's test and Dunnett's test).

3 One-factor analysis of variance (ANOVA) is a statistical test which is employed in comparing the means of many groups. It may be regarded as an "extension" of Student's $t$-test, which is limited to analyzing the differences only between two groups. ANOVA is free from this limitations. If there is a need to compare more than two groups, instead using the $t$-test several times, an one-factor analysis of variance is applied (see [Heckman, Leamer 2001; SPSS... 1999]).

${ }^{4}$ Assessing the equality of variances in analyzed subgroups is one of the assumptions that has to be met while using the tests for independent samples. If the assumption is not valid, then a variation of the $t$-test that does not require equal variances is used (see [Bedyńska, Cypryańska (eds.) 2013, pp. 182-183]).

${ }^{5}$ In ANOVA the value of F-statistic is not sufficient to show which groups are different from one another. What is known is that there is a difference between them. In order to detect where the differences occur it is crucial to carry out multiple tests, the so-called post hoc tests. Those tests give an answer to the question regarding which of the analyzed groups are different from others. 
Table 2. The mean values for the selected questions of the original questionnaire

\begin{tabular}{|c|c|c|c|c|c|}
\hline No. & Question & Sum & Healthcare & Education & $\begin{array}{l}\text { Higher } \\
\text { education }\end{array}$ \\
\hline \multicolumn{6}{|c|}{ Type of work } \\
\hline $3 a$ & High emotional stress & 5.71 & 6.42 & 5.48 & 4.93 \\
\hline $3 \mathrm{~b}$ & Great physical strain & 4.43 & 6.29 & 3.02 & 3.23 \\
\hline $3 \mathrm{c}$ & I am mostly responsible for my work results & 6.48 & 6.45 & 6.26 & 6.74 \\
\hline $3 \mathrm{~d}$ & My work involves contact with others & 9.53 & 9.57 & 9.63 & 9.37 \\
\hline $3 \mathrm{e}$ & A stressful relationship with a supervisor & 4.00 & 4.41 & 3.80 & 3.60 \\
\hline $3 \mathrm{f}$ & Stressful relationships with co-workers & 3.26 & 3.62 & 2.72 & 3.30 \\
\hline $3 g$ & Too much bureaucracy & 7.16 & 7.10 & 7.33 & 7.07 \\
\hline $3 \mathrm{~h}$ & A dynamic environment/a necessity to adapt & 6.53 & 6.59 & 6.52 & 6.47 \\
\hline $3 \mathrm{i}$ & An adequate remuneration for work & 4.13 & 4.18 & 3.80 & 4.42 \\
\hline $3 \mathrm{j}$ & Little success at work & 5.01 & 5.55 & 5.02 & 4.26 \\
\hline $3 \mathrm{k}$ & I feel that my work suits me & 8.24 & 8.25 & 8.30 & 8.14 \\
\hline 31 & I maintain a work-life balance & 6.28 & 6.98 & 6.35 & 5.16 \\
\hline $3 \mathrm{~m}$ & I am satisfied with my work & 7.50 & 7.60 & 7.33 & 7.53 \\
\hline $3 n$ & I would like to change my job & 3.18 & 3.41 & 3.13 & 2.91 \\
\hline 30 & I wish I could take some time off work & 6.76 & 6.79 & 7.46 & 5.98 \\
\hline $3 p$ & I can influence the way I do my work & 7.55 & 7.37 & 7.57 & 7.81 \\
\hline \multicolumn{6}{|c|}{ A subjective assessment of the knowledge of burnout } \\
\hline $7 \mathrm{a}$ & I have sufficient understanding of burnout & 7.35 & 8.23 & 6.72 & 6.77 \\
\hline $7 \mathrm{~b}$ & $\begin{array}{l}\text { I could recognize the symptoms of burnout if } \\
\text { they affect me personally }\end{array}$ & 7.21 & 7.95 & 7.02 & 6.35 \\
\hline $7 \mathrm{c}$ & $\begin{array}{l}\text { I am able to tell whether somebody else shows } \\
\text { the symptoms of burnout }\end{array}$ & 6.60 & 7.47 & 6.17 & 5.86 \\
\hline \multicolumn{6}{|c|}{ Burnout is a serious problem among the members of my professional group } \\
\hline 12 & I agree with that opinion & 7.68 & 7.63 & 7.73 & 7.70 \\
\hline \multicolumn{6}{|c|}{ It is hard to openly admit to being burnt-out at my workplace } \\
\hline 14 & I agree with that opinion & 6.17 & 5.68 & 5.75 & 7.19 \\
\hline
\end{tabular}

Source: own calculations.

In the case of question no. 3, which considered the type of work, Levene's test showed significant differences between the mean values for four categories $-3 \mathrm{a}, 3 \mathrm{~b}$, $3 \mathrm{j}$ and $31(\alpha \leq 0,05)$. Those differences mainly concerned the perception of these categories by the healthcare and higher education respondents (the significance of the differences was identified in all the four categories). Additionally, the difference of the mean values between the healthcare and education professionals was also diagnosed to be significant for category $3 b$.

The question no. 7, which refers to the self-assessment of one's knowledge of burnout, showed no statistically significant equality of variances for any category $(\alpha \leq 0.05)$. Nevertheless, for all the categories the differences between mean values 
were significant. In questions $7 \mathrm{a}$ and $7 \mathrm{c}$ the statistically significant differences concerned the following pairs: the healthcare versus education sector and the healthcare versus higher education sector. In question $7 \mathrm{~b}$ those differences were observed solely between the healthcare and education sector.

A test for question no. 12, regarding the scale of the burnout problem in a particular professional group, diagnosed no significant differences between the means of the observed pairs. In question no. 14, where the respondents were asked to assess how difficult it is to admit to being burnt-out at their workplace (no equality of variances), the significant differences between the mean values $(\alpha \leq 0.05)$ refer to the context of higher education, where admitting to one's burnout is more problematic than in other sectors.

To observe the differences between the surveyed professional groups in terms of burnout symptoms (but also in terms of the factors that can minimize the negative effects of this syndrome) the answers to following questions were taken into account: question no. 4 (How often do you feel like not going to work, when thinking about your current job?) and question no. 5 (Do you take part in any leisure or personal development activities, other than your professional and domestic duties?). The results of the survey are displayed in Figures 1 and 2.

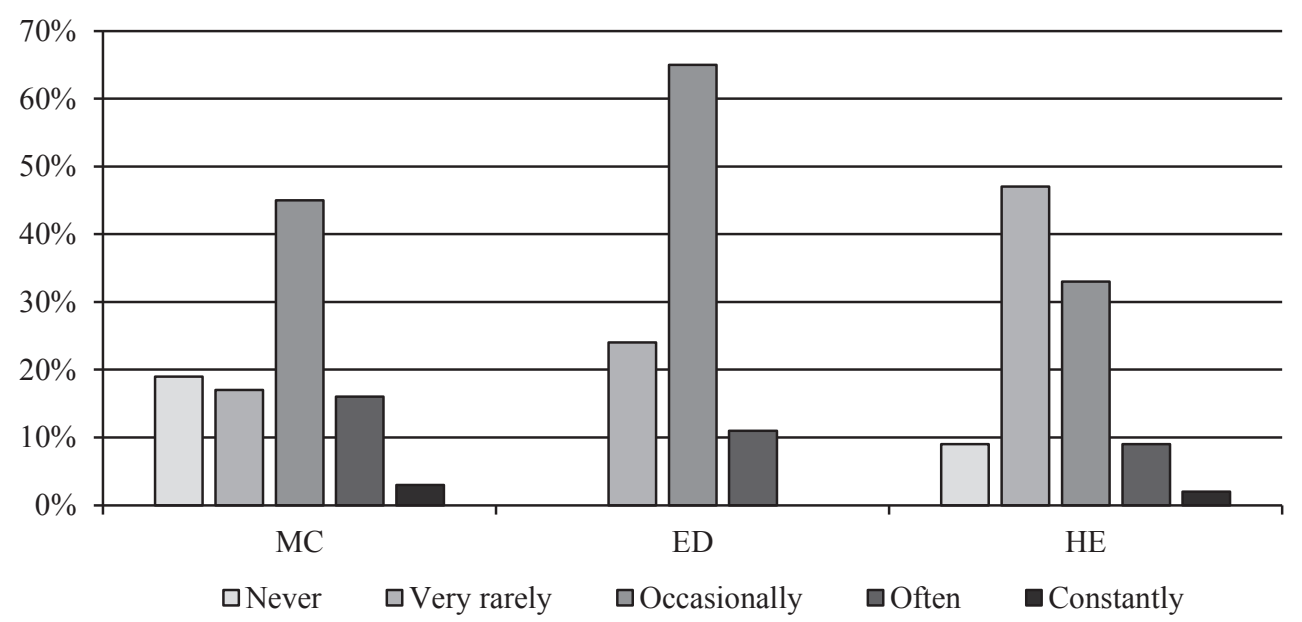

Figure 1. The frequency of feeling aversion to work

Source: own calculations.

Most of the people who never or rarely experience aversion to work can be found among the representatives of higher education (56\%), education (24\%) and healthcare $(36 \%)$. The most frequent answer given by the health service employees was "rarely". It is worth emphasizing that the answers of the education professionals did not include either "never" or "constantly". 


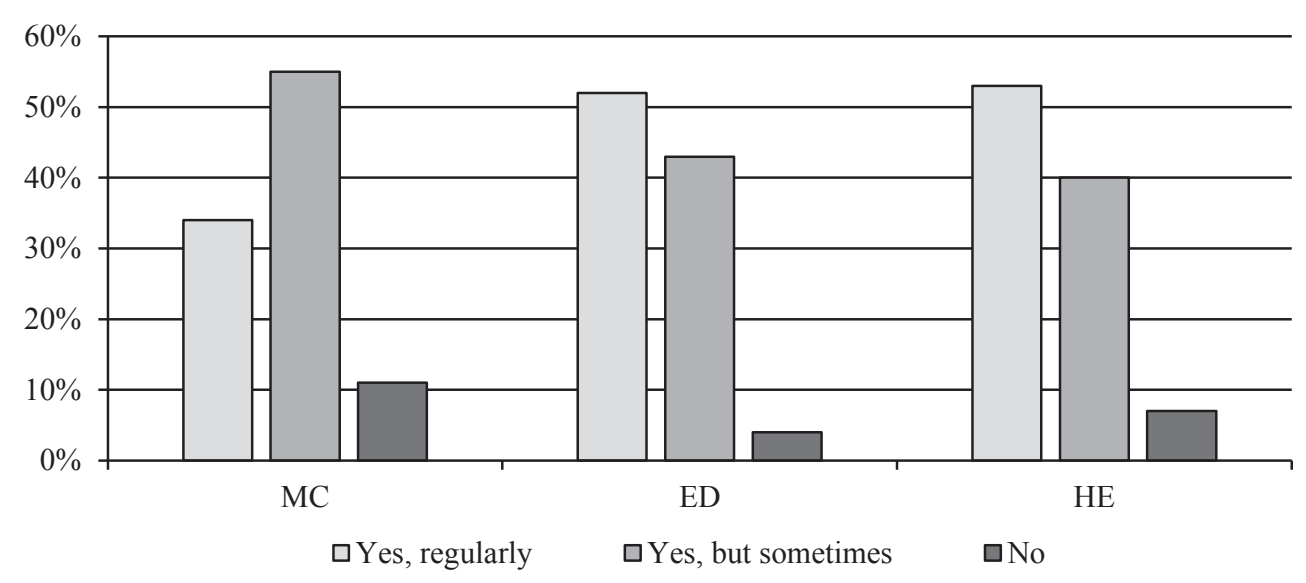

Figure 2. Leisure and personal development activities (hobby)

Source: own calculations.

What is both intriguing and disturbing is the fact that the healthcare professionals engage in considerably less activities devoted to leisure and personal development than others. What is also unsettling is that as many as $11 \%$ of the respondents admitted that they have no alternative to work and domestic responsibilities.

After using a tool for measuring burnout and its components (the LBQ test) it could be concluded that the syndrome is common among the Polish health care, education and higher education professionals. A comparison of the respondents' scores in terms of emotional exhaustion (which is a symptom that correlates with occupational stress the most) revealed that they experience this aspect of burnout with a similar intensity. $75 \%$ of the respondents in health care reported being moderately exhausted in terms of emotions, while $8 \%$ of them experienced the symptoms to a high degree. In the group of teachers, $72 \%$ of the respondents described their emotional exhaustion to be moderate and 13\% to be high, which demonstrates a severe stress and work overload. $77 \%$ of the surveyed research and teaching staff felt moderately exhausted, while $14 \%$ scored high level on the scale.

It is not possible to draw conclusions about the global level of burnout exclusively on the basis of the level of emotional exhaustion and without analyzing other indicators [Noworol, Marek 1993]. Nevertheless, the diagnosis of this component only shows that the respondents' results are alarming in view of the level of psychophysical exhaustion, lowered immunity and stress levels at workplace. In terms of thelowered engagement in relationships, which is often referred to as depersonalization or cynicism [Maslach, Leiter 2010;2011;2012], the highest scores were achieved by the representatives of higher education (which is the least investigated professional group in the aspect of burnout). $19 \%$ of the academics declared to have experienced a high level of a distorted engagement in occupational relationships and as many as 
$72 \%$ reported the average level of cynicism and depersonalization. $8 \%$ of the health care workers and $11 \%$ of the education workers achieved high scores on the scale as well. $35 \%$ of the teachers scored a low level of depersonalization and lowered engagement (to compare: in the higher education branch only $9 \%$ of respondents achieved low scores).

The results that have been presented may arouse controversy with regard to the group of academic teachers, whose basic professional duties include contacts with the recipients of educational services, i.e. students. Given the nature of their work, the present situation of the research and teaching staff (expectations, requirements and employment status) could be analyzed in terms of the reasons that had given rise to such high levels of emotional exhaustion in this group. It is possible that academics are unable to concentrate more on the research aspect of their work because of being under excessive strain of administrative and teaching duties. What is more, the professional group may suffer from the deficit of interpersonal skills related to solving difficult situations that include interactions with students or colleagues. In higher education in Poland there is still no concrete support meant for academics that would cover the development of teaching or mentoring skills, vital to effective fulfillment of the role of an academic teacher.

As for the diagnosis of the component regarding lowered sense of effectiveness, it is worth noting that only $7 \%$ of the surveyed academic teachers reported high levels of this aspect of burnout, while 19\% of them claimed that the level of their professional effectiveness is high. By comparison, in the group of school teachers, $13 \%$ of the respondents said that their work produced no effects, whereas $24 \%$ of them experienced job satisfaction and perceived the effects of their work. In conclusion: academics feel rather effective or highly effective as for their profession. At the same time they achieve high scores on the scale of lowered engagement in occupational relationships. Higher education workers also scored the highest (and the least favorable) results in the existential aspect, which is described in terms of career disappointment. As many as $93 \%$ of the surveyed researchers were disappointed in their work at least to an average degree (including 12\% to a high degree), while the result of this indicator among the health care and education workers was respectively $70 \%$ and $78 \%$.

\section{A comparison of the results of the $L B Q$ and the original questionnaire}

Questions no. 4 (the frequency of feeling aversion to work) and no. 5 (participating in leisure activities except for work and domestic responsibilities), that had been part of the original questionnaire, were used by the authors to test the concurrence of the traits described in those questions and the level of burnout. To this end a cross table was used (SPSS, ver. 24.0) together with the Chi-Square statistic. The results are: 
1. In the case of question no. 4 there is an observable positive correlation between the level of work aversion and the level of burnout in the areas of: exhaustion, disappointment and effectiveness.

2. In the case of question no. 5 it is visible that the fact of having a hobby influences the level of burnout in the area of disappointment and effectiveness, making it lower.

Table 3. The contingency tables comparing question no. 4 and the areas of burnout

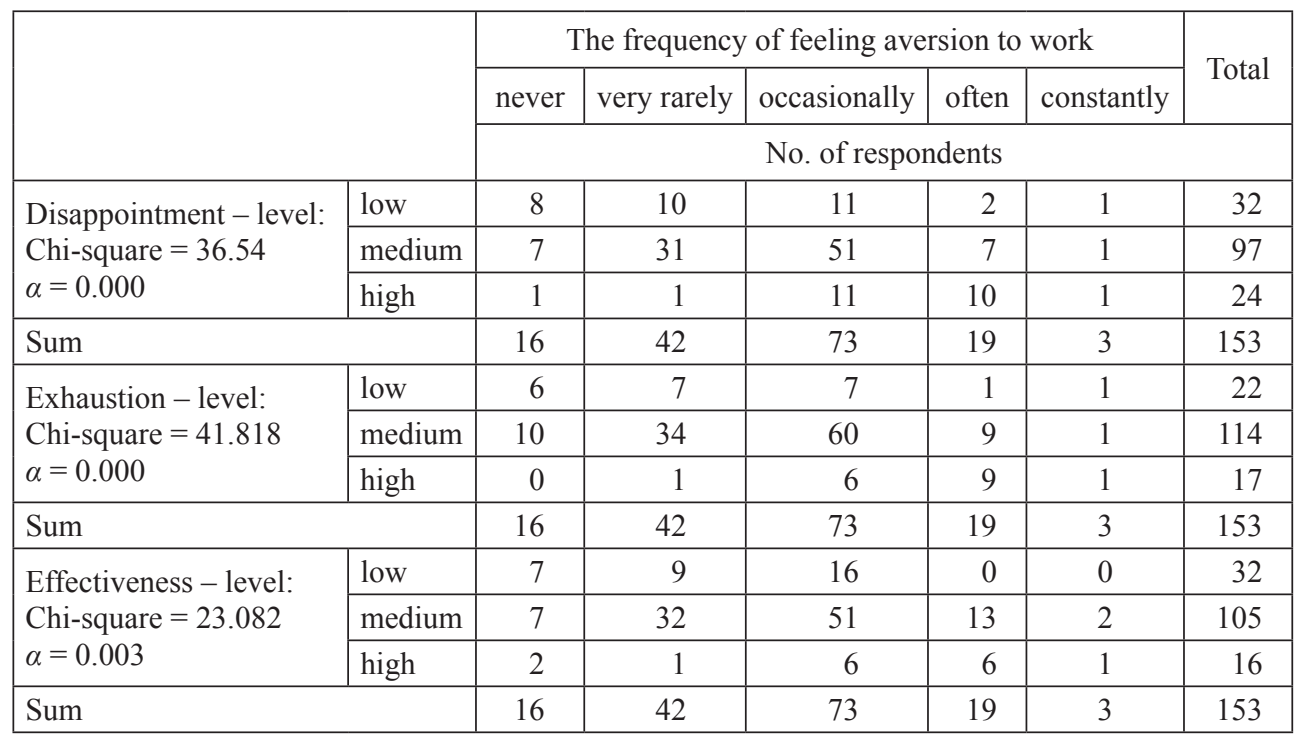

Source: own calculations.

Table 4. The contingency tables comparing question no. 5 and the areas of burnout

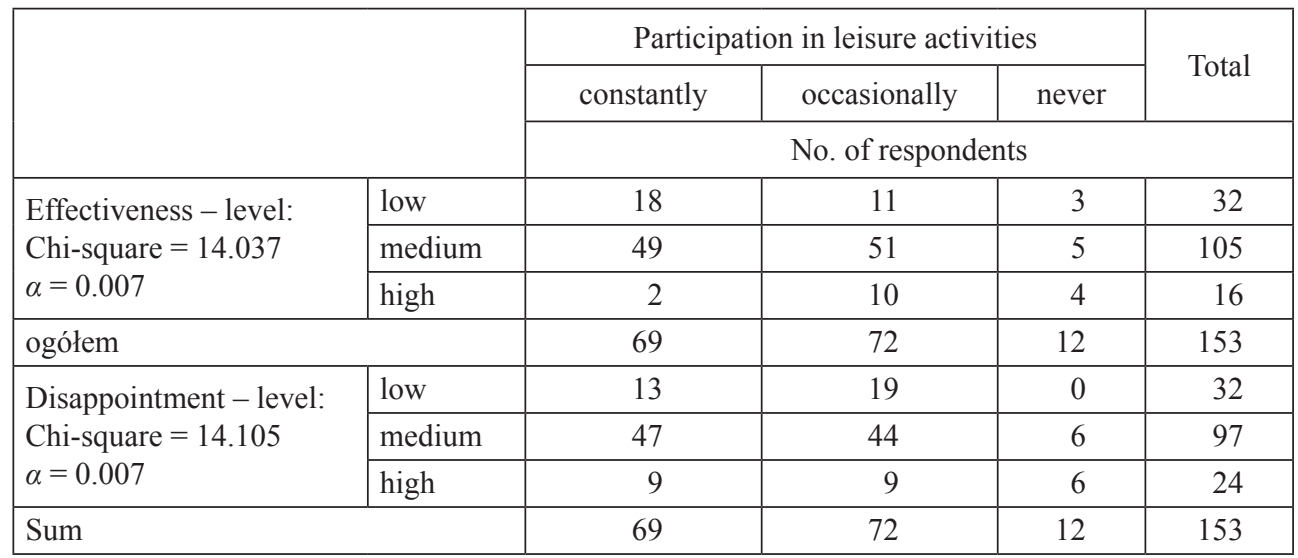

Source: own calculations. 
Tables 3 and 4 display the contingency table containing the aforementioned questions and the aspects of burnout (where the correlations have been observed) together with the results of Pearson's Chi-squared test.

Questions no. 3 and 4 were used for searching for independent variables in discriminative models [Gruszczyński 2002]. The models were constructed for the whole sample as well as for the particular representatives of the professional groups. Due to the unsatisfactory relevance of the classification, which ranged from $30 \%$ to $74 \%$, the models cannot be recognized as having a desirable quality. The highest accuracy was observed in the area of exhaustion and disappointment, the lowest in the area of involvement. As for the professional groups, the education sector recorded the highest accuracy.

\section{Concluding remarks}

The present research on the phenomenon of burnout simultaneously carried out in healthcare, education and higher education, is an attempt to identify similarities and differences between three professional groups. It provides the answers to the initial research questions. The following concluding remarks can be made:

- The phenomenon of burnout is widely perceived in all of the analyzed professional groups. This claim is supported by the high LBQ Questionnaire results as well as the responses to the selected questions from the original questionnaire (especially questions no. 7, 12 and 14).

- Burnout is a phenomenon that is perceived by the respondents inconsistently. The main differences concern the level of understanding of the syndrome (the healthcare professionals demonstrated the highest one) and the level of difficulty in formally informing an employer of burnout.

- Academic professionals experience the typical symptoms of burnout. What is more, the results of the analyses demonstrate that the group is distinctly different from other groups. It achieved high scores in most of the areas (the LBQ Questionnaire). On the other hand, it is characterized by the lowest level of work aversion.

- The main factors responsible for the differences in the perception of burnout in the surveyed groups are associated with the respondents' type of work, which is illustrated by the answers to question no. 3 of the original questionnaire.

The findings of this study suggest that the problem of burnout in Poland requires further research. First of all, this can include:

- Extending the scope of research in higher education, as there have been no studies in Poland dedicated to this professional group so far. The current preliminary study shows that the group has complex nature - although it has a high status its members feel underestimated and disappointed. Such conditions can lead to an escalation of the problem in the coming years. 
- Carrying out a study of the employers' perception as well as comparing the employers' and employees' opinions in terms of burnout (in healthcare, education and higher education).

- Comparing the international research on burnout.

Given the aims of the international research project that has been a framework for this paper (building a useful model for the prevention of burnout) what seems to be particularly important is to conduct a longitudinal research that would illustrate the dynamics of the respondents' burnout before and after taking the preventive action.

\section{Bibliography}

Bedyńska S., Cypryańska M. (eds.), 2013, Statystyczny drogowskaz 1. Praktyczne wprowadzenie do wnioskowania statystycznego, Wydawnictwo Akademickie Sedno Sp. z o.o., Warszawa.

Gruszczyński M., 2002, Modele i prognozy zmiennych jakościowych w finansach i bankowości, Wydawnictwo SGH, Warszawa.

Heckman J., Leamer E., 2001, Handbook of Econometrics, vol. 5, Elsevier, Amsterdam.

Maslach Ch., 1998, A Multidimensional Theory of Burnout, [in:] Cooper C.L. (ed.), Theories of Organizational Stress, Oxford University Press, New York.

Maslach Ch., 2011, Engagement research: Some thoughts from a burnout perspective, European Journal of Work and Organizational Psychology, 20, pp. 47-52.

Maslach Ch., Jackson S., 1981, The measurement of experienced burnout, Journal of Occupational Behaviouor, vol. 2, pp. 99-113.

Maslach Ch., Jackson S.E, Leiter M.P., 1996, MBI Manual. 3rd ed., Mountain View, CA: CPP, Inc.

Maslach Ch., Leiter M.P., 2008, Early predictors of Job burnout and engagement, Journal of Applied Psychology, vol. 93, no. 3, pp. 498-512.

Maslach Ch., Leiter M.P., 2010, Pokonać wypalenie zawodowe. Sześć strategii poprawiania relacji z praca, Oficyna Wolters Kluwer business, Warszawa.

Maslach Ch., Leiter M.P., 2011, Prawda o wypaleniu zawodowym. Co robić ze stresem w organizacji, Wydawnictwo Naukowe PWN, Warszawa.

Maslach Ch., Leiter M.P., Jackson S.E., 2012, Making a significant difference with burnout interventions: Researcher and practitioner collaboration, Journal of Organizational Behavior, 33, pp. 296-300 .

Molenda M., Hąbek P., 2015, Wypalenie zawodowe - charakterystyka zjawiska, sposoby przeciwdziatania, Jakość i Bezpieczeństwo, 3(12).

Noworol Cz., Marek T., 1993, Typology of burnout, methodology of the modelling of the syndrome, Polish Psychological Bulletin, vol. 24, no. 4, pp. 319-326.

Santinello M., 2008, LBQ. Link Burnout Questionnaire, Manuale, Firenze, Giunti O.S. Organizzazioni Speciali.

Santinello M., 2014, LBQ. Kwestionariusz wypalenia zawodowego. Podręcznik, Pracownia Testów Psychologicznych Polskiego Towarzystwa Psychologicznego, Warszawa.

SPSS Advanced Models, 1999, SPSS Incorporation, Chicago. 


\section{WYPALENIE ZAWODOWE I JEGO KORELATY NA PODSTAWIE BADAŃ EMPIRYCZNYCH WŚRÓD PRACOWNIKÓW EDUKACJI, SZKOLNICTWA WYŻSZEGO ORAZ OPIEKI MEDYCZNEJ}

Streszczenie: Celem artykułu jest przedstawienie wyników badań empirycznych w zakresie wypalenia zawodowego i jego korelatów w grupie polskich pracowników sektora: edukacji, szkolnictwa wyższego oraz opieki medycznej. Łącznie przebadano 153 osoby reprezentujące poszczególne branże z wykorzystaniem kwestionariusza wypalenia zawodowego Santinello oraz autorskiego kwestionariusza dotyczącego percepcji zjawiska wypalenia (m.in. awersji do pracy, dodatkowych zainteresowań poza pracą zawodową, gotowości do przyznania się do doświadczania objawów wypalenia itd.). Badanie pilotażowe zrealizowano w czerwcu oraz lipcu $2017 \mathrm{r}$.

Słowa kluczowe: wypalenie zawodowe, analiza statystyczna, wyczerpanie emocjonalne, cynizm, obniżone poczucie osiągnięć osobistych, typ pracy a wypalenie, demograficzne korelaty wypalenia zawodowego. 